\title{
Finnish Elementary School Teachers' Attitudes Toward Gifted Education
}

\author{
Laine, Sonja
}

2019

Laine , S , Hotulainen, R \& Tirri , K 2019 , ' Finnish Elementary School Teachers' Attitudes

Toward Gifted Education ' , Roeper Review , vol. 41 , no. 2 , pp. 76-87 . https://doi.org/10.1080/02783193.2019.1592

http://hdl.handle.net/10138/321178

https://doi.org/10.1080/02783193.2019.1592794

unspecified

acceptedVersion

Downloaded from Helda, University of Helsinki institutional repository.

This is an electronic reprint of the original article.

This reprint may differ from the original in pagination and typographic detail.

Please cite the original version. 
Finnish elementary school teachers' attitudes toward gifted education

Sonja Laine ${ }^{1}$, Risto Hotulainen ${ }^{1}$, and Kirsi Tirri ${ }^{2}$

${ }^{1}$ Faculty of Educational Sciences, University of Helsinki

PO Box 9, FI-00014 University of Helsinki, Finland

${ }^{2}$ Helsinki Collegium for Advanced Studies

PO Box 4, FI-00014 University of Helsinki

Corresponding author: sonja.laine@helsinki.fi 


\title{
Finnish elementary school teachers' attitudes toward gifted education
}

\begin{abstract}
This study examined Finnish elementary school teachers' $(N=212)$ attitudes toward the gifted and their education. On a general level, teachers' attitudes toward the gifted education were slightly positive. Teachers saw that gifted students have social value and that they need special services. The results of teachers' attitudes toward specific gifted education options were in line with earlier Finnish research, as teachers supported differentiated teaching but were more negative toward acceleration or separating gifted into their own groups. However, despite the strong support to differentiated teaching for the gifted, teachers' positions toward practice were more skeptical.
\end{abstract}

Keywords: gifted education, attitudes, teachers, explorative factor analysis, differentiated teaching 


\section{Introduction}

Teachers' attitudes toward gifted education have intrigued many researchers (e.g., Bégin, \& Gagné, 1994; Cross, Cross, \& Frazier, 2013; Jung, 2014; Lassig, 2009; McCoach \& Siegle, 2007; Tallent-Runnels, Tirri, \& Adams, 2000; Tirri, Tallent-Runnels, Adams, Yuen, \& Lau, 2002; Tirri \& Uusikylä, 1994; Troxclair, 2013). This area has been regarded as an important one to study, since it is widely assumed that teachers should have appropriate attitudes toward the gifted in order to address gifted students' needs effectively (Lassig, 2003; Troxclair, 2013). Furthermore, knowledge of teachers' attitudes has been seen as valuable in planning the implementation of gifted education (Cross et al., 2013) and in ensuring that gifted students have appropriate opportunities and educational interventions (Jung, 2014).

In general, attitudes can be defined as peoples' evaluation of objects (e.g., oneself, other people, issues) (e.g., Ajzen, 2001; Ajzen \& Fishbein, 2000) on a scale ranging from positive to negative, such as good - bad, harmful - beneficial, pleasant - unpleasant, or likable - unlikable (Ajzen, 2001). Further, attitudes can be defined as evaluative abstractions in which cognitive and affective reactions are integrated and summarized, and can vary in strength (Crano \& Prislin, 2006). Attitudes have been seen as predispositions that consistently affect actions; accordingly, attitudes have been regarded as an intriguing field of research in teaching and teacher education for a long time (Richardson, 1996). Some researchers, such as McCoach and Siegle (2007), believe that it is important to assess, predict, or even change teachers' attitudes. Attitudes have been called “crown jewels" because they predict behavior (Crano \& Prislin, 2006, p. 360); however, the link between attitude and behavior is complex (Ajzen \& Fishbein, 2000; Crano \& Prislin, 2006).

This study attempts to broaden the picture of teachers' attitudes toward gifted education. The aim is to obtain more information about teachers' attitudes toward gifted and their education, 
and about teachers' attitudes toward differentiated teaching for the gifted. Furthermore, this study aims to update the earlier knowledge of Finnish teachers' attitudes toward gifted education (e.g. Ojanen \& Freeman, 1994; Tallent-Runnels et al., 2000; Tirri et al., 2002; Tirri \& Uusikylä, 1994). In order to obtain knowledge about Finnish elementary school teachers' general attitudes toward gifted education, we have used Gagné and Nadeau's (1991) instrument “Opinion about the gifted and their education." Furthermore, based on literature, we created new survey items to use in this study in order to assess teachers' attitudes toward differentiated teaching for the gifted, and the practical obstacles to differentiation.

\section{Attitudes toward gifted education}

Earlier findings on teachers' attitudes toward the gifted and their education are varying. Some research has shown that teachers mostly have a positive and supportive attitude toward recognizing and supporting gifted students' needs in general (e.g., Lassig, 2009; McCoach \& Siegle, 2007; Troxclair, 2013). On the other hand, some studies have indicated that teachers' attitudes are more neutral in certain respects (McCoach \& Siegle, 2007). Negative attitudes have also been reported, especially concerning accelerating students identified as gifted (Lassig, 2009; Troxclair, 2013). Both ambivalent (Lassig, 2009) and negative attitudes (Troxclair, 2013) to ability grouping have been reported. These negative (or at best neutral) stances are problematic, since acceleration and ability groupings are known to be the most effective interventions for supporting gifted students (cf. Assouline, Colangelo, VanTassel-Baska, \& Lupkowski-Shoplik, 2015; Colangelo, Assouline, \& Gross, 2004a; Colangelo, Assouline, \& Gross, 2004b; Hattie, 2009; Wood, Portman, Cigrand, \& Colangelo, 2010). 
Research on teachers' attitudes toward differentiated teaching for the gifted is scarce. This is a clear lacuna in educational research, given that differentiated teaching is a core strategy for addressing the diversity of students " needs, interests, and abilities in regular classrooms (Tomlinson, 1999) and is also an essential way for addressing the needs of the gifted (e.g., Latz, Speirs Neumeister, Adams, \& Pierce, 2009; Mönks \& Katzko, 2005). Studies involving pre-service teachers have indicated that these teachers have moderately positive attitudes toward differentiated teaching for the gifted (Megay-Nespoli, 2001) and that there is agreement that individual differences should be taken into account (Moon, Callahan, \& Tomlinson, 1999). However, there are some indications that teachers do not implement differentiated teaching on a regular basis (Archambault et al., 1993; Latz et al., 2009; Westberg, Archambault, \& Brown, 1997; Westberg, Archambault, Dobyns, \& Salvin, 1993), that gifted students are not often included in a group that is viewed as needing differentiated teaching (Hertberg-Davis, 2009), and that teachers focus more on the needs of struggling learners (Brighton, Hertberg, Moon, Tomlinson, \& Callahan, 2005). In Finland, Tirri and Uusikylä (1994) found that, among the various gifted educational practices in Finland, the country's elementary school teachers favored differentiated teaching in regular classrooms. Elementary school teachers were found to be more negative to the idea of separate schools or classes than were secondary school teachers (Tirri \& Uusikylä, 1994). Nevertheless, differentiated teaching in general has been found to be the second biggest pedagogical challenge that Finnish elementary school teachers have faced during their career (Atjonen et al., 2008). Furthermore, recent Finnish research indicated that Finnish teachers mostly see gifted as a group needing differentiated teaching (Laine \& Tirri, 2016).

Researchers have further attempted to examine the factors predicting teachers' attitudes. It has been found, among other things, that those who have more knowledge about gifted children 
(e.g., Copenhaver \& McIntyre, 1992; Jones \& Southern, 1992; Morris, 1987) and/or have experience working with the gifted (Bégin \& Gagné, 1994; Copenhaver \& McIntyre, 1992; Dettmer, 1985; Townsend \& Patrick, 1993) have a more positive attitude toward these children. In addition, contact with the gifted persons has been found to be a factor predicting positive attitudes toward special gifted programs and provisions (Bégin \& Gagné, 1994; Jung, 2014). However, results on the predictors of attitudes are ambivalent as the same predictors are not necessarily statistically significant in all studies, and many of the predictors have been tested only once (Bégin \& Gagné, 1994; McCoach \& Siegle, 2007).

Surveys have indicated that there is a lack of consensus about whether or not the gifted are seen as needing special services (Bégin \& Gagné, 1994). On the one hand are those who seem to reject special services completely, while on the other hand, there are those who support such services wholeheartedly (Bégin \& Gagné, 1994; Cross et al., 2013). Furthermore, in their study, McCoach and Siegle (2007) concluded that, while in general teachers' attitudes were neutral, some teachers had very positive attitudes and others had very negative attitudes. McCoach and Siegle (2007, p. 253) also acknowledged that "practitioners in the field of gifted education should assess teachers' attitudes on an individual basis rather than assuming that 'all teachers' harbor positive or negative attitudes toward gifted education."

Earlier research on Finnish teachers' attitudes included cross-cultural comparisons. One of the earliest studies examined and compared the attitudes and experiences of head teachers, class teachers, and highly able students toward education of the highly able in Finland and Britain (Ojanen \& Freeman, 1994). It was found that Finnish teachers preferred to keep highly able students in normal classroom routines and with other students and make arrangements for the gifted in ordinary, mixed-ability classes and schools. The teachers wanted to promote the social 
skills of the highly able, using them as good examples for the less talented students, and they were doubtful about the value of isolating the gifted (Ojanen \& Freeman, 1994). Later research (TallentRunnels et al., 2000; Tirri et al., 2002) in which Gagné and Nadeau's (1985) 60-item scale was used has shown similar results. It was found that Finnish teachers were more concerned about the negative side effects of special classes and other special arrangements outside the regular classroom than were their American colleagues (Tallent-Runnels et al., 2000). Furthermore, using a Bayesian predictive discriminant analysis, the research has revealed that there are cultural differences in the attitudes of Finnish, American, and Hong Kong teachers (Tirri et al., 2002). The items that produced the most discriminating answers were: "There are no gifted children in our school"; "The gifted should spend their spare time helping those who progress less rapidly"; and "All children are gifted." Finnish teachers disagreed strongly with the first item, showed opposing attitudes toward the second, and agreed most with the last (Tirri et al., 2002).

\section{Context}

This research has been carried out in the context of the Finnish school system. Finland's school situation serves as an interesting context for examining teachers' attitudes toward gifted education because the system is highly egalitarian. The main educational principle has been to maintain social equity by taking care of the weakest students (Tirri \& Kuusisto, 2013), and the largest share of support has been directed to students with special educational needs (Kumpulainen \& Lankinen, 2012; Niemi, 2012).

Until late 1990's, social equity was regarded as the back bone of the economic and social well-being of Finnish society having a respected public education system, which guarantees to every citizen a high level of education regardless of gender, place of residence, age, language and 
economic status (Simola, Rinne \& Kivirauma, 2002). However, partly due to the heavy economic depression, which hit Finland harder than many other developed Western countries during the 1990's, there was increasing pressure for economic change, and for more market-driven and individualized discourse in educational contexts as well (Simola et al. 2002). Gradual rhetorical shift towards more individualized values became concrete in education when the Finnish "National Core Curriculum in Basic Education 2004" was published. For the first time, there was a notion that the individual student is entitled to teaching which corresponds to his or her personal abilities, special needs and the development of such abilities (FNBE, 2004).

The position of students' individual needs has been strengthened further in more recent versions of the Finnish core curriculum for basic education: Both the earlier amendments and additions to the national core curriculum for basic education (Finnish National Board of Education [FNBE], 2011) and the newest national core curriculum (FNBE, 2014) emphasize differentiation as the pedagogical basis of teaching. Thus, all students, including the gifted, should be given education that addresses their individual needs. In this respect, the system is highly developed with regard to gifted education (Mönks \& Pflüger, 2005). Furthermore, American policy experts Finn and Wright (2015) acknowledged that a key ingredient in Finland's success is the belief in inclusive, uniform, child-centered instruction delivered in fundamentally similar schools by exceptionally well-prepared teachers whose training and skills include the capacity to differentiate their instruction according to the needs, abilities, and prior achievements of their pupils.

However, there are still strong impressions even nowadays that the Finnish school system and its teachers work more for social equality than for individual equality. One good example where this individual equality is actualized in education is gifted students. In viewing the Finnish school system from this perspective, it can be seen that there is no official gifted education policy 
in Finland (Tirri \& Kuusisto, 2013), nor are there any official definitions of giftedness or any identification criteria (Mönks \& Pflüger, 2005). Furthermore, even though Finnish classroom teachers are highly educated, since all have professional academic education and hold master's degrees (Tirri, 2014), there is no mandatory teacher education for dealing with gifted students and their needs. The education and knowledge teachers acquire about gifted education depend on the universities in which they study and their own interests.

Finn and Wright (2015) also identified a "Finnish mindset," in which "standing out" except in music and sports is unfashionable, in effect, a fundamental Finnish value that encourages both inclusion and uniformity in education (Finn \& Wright, 2015). Thus, in Finland, the reluctance to promote giftedness is apparent especially with regard to intellectual giftedness (Persson, 2011). In this egalitarian atmosphere, it might be hard to discuss giftedness or to identify someone or oneself as gifted. This might have led to a situation in which all students are believed to be gifted or to the idea that those who are extremely gifted can take care of themselves (Laine, 2010; Tirri \& Kuusisto, 2013).

Not least, egalitarian contexts have been described as hostile to giftedness or, at best, only support gifted education in mixed-ability settings (Moon \& Rosselli, 2000). In Finland, as in many egalitarian countries, it is ultimately up to teachers to decide whether the needs of the gifted are addressed in practice (Laine \& Tirri, 2016; Finn \& Wright, 2015). Thus, it is especially important and interesting to address teachers' attitudes toward gifted education in an egalitarian context.

\section{The present study}


This study attempts to broaden the picture of teachers' attitudes toward gifted education. The aim is to explore teachers' general attitudes toward gifted education and their attitudes toward differentiated teaching for he gifted. The research questions are as follows:

1) What are Finnish elementary school teachers' attitudes toward gifted education?

2) What are Finnish elementary school teachers' attitudes toward differentiated teaching as a means to respond to the needs of the gifted students?

Both abovementioned research questions were explored in relation to background variables such as gender, age, years of teaching, and school size. Furthermore, in accordance with earlier research (cf. Bégin \& Gagné, 1994; Copenhaver \& McIntyre, 1992; Dettmer, 1985; Jung, 2014; Townsend \& Patrick, 1993), the relation between teachers' attitudes and their perceptions of their own giftedness, having gifted as close contacts, and experience in teaching the gifted were examined.

\section{Methods}

\section{Procedure - Participants}

We invited 161 randomly selected municipal educational administrators from all six of Finland's mainland regional state administrative agencies to participate in the study. Among these municipalities, 54 agreed to participate. The administrators were then asked to send a response request that we supplied together with an Internet link to our questionnaire to all elementary school principals in their respective municipalities. The principals were given the task of sending the link to the teachers in their school. The reason for choosing this procedure was to obtain a large and representative sample of Finnish elementary school teachers from all parts of Finland. 
Ultimately, a total of 212 teachers returned the questionnaire. The exact response rate is impossible to calculate, because information on how many of the schools and teachers received the Internet link is unknown. The response rate can be assumed to be low, since we do know that the teachers came from a total of 44 different municipalities. However, the richness of the data also arises from the fact that the respondents came from different municipalities and schools and from all regions of mainland Finland.

The majority of the respondents were female (77\%). The gender distribution is close to the national gender distribution of teachers: $74 \%$ of elementary school and pre-school teachers are known to be female (Kumpulainen, 2011). Also the age distribution was similar to that of the national level in Finland (Kumpulainen, 2011): approximately one-third of the teachers were under 40 years of age (33\%), one-third were between 40 and $49(35 \%)$, and one-third were more than 50 years $(32 \%)$. In this respect the sample represent very well the total teacher population in Finland. Furthermore, most teachers were experienced, having taught over 20 years $(n=85 ; 40 \%)$ or for 10 to 19 years $(n=71 ; 33 \%)$, while a proportional share of the two less experienced groups was smaller: $5-9$ years $(n=29 ; 14 \%)$ and $0-4$ years $(n=27 ; 13 \%)$.

Furthermore, at the beginning of the survey, in addition to the background variables such as age, gender, and work experience, teachers were asked to rate their opinions of 10 background items on a 9-point Likert-scale ( $1=$ I totally disagree and 9=I totally agree). This was done in order to provide additional information about the study sample. As indicated in Table 1, teachers had a slightly negative perception about their current knowledge on gifted and their education. Furthermore, they quite unanimously expressed desire for more knowledge regarding the topic. They claimed to be trying to address gifted students' needs in practice, but were not sure whether the methods they used were clear. Results indicated a neutral view toward teachers' own 
giftedness, but they agreed more strongly with having a gifted family member or someone gifted in their vicinity. Most saw that the development of gifted education is an important goal for the future.

Please insert Table 1 about here

In sum, the background variables provided a clear picture about respondents' characteristics, which for the most part were in line with earlier studies, indicating that respondents were not exceptional advocates of gifted education (see Kuparinen 1995).

\section{Measures}

Opinions about the gifted and their education

For this research, the widely-used instrument "Opinions about the gifted and their education” (e.g., Cross et al., 2013; Jung, 2014; Lassig, 2009; McCoach \& Siegle, 2007; Troxclair, 2013) devised by Gagné and Nadeau (1991) was chosen to assess teachers' general attitudes toward the gifted and their education. As the instrument's original language was English, it was translated into Finnish. The Finnish translation was translated back into English using the language service of the University of Helsinki in order to verify the initial translation.

The instrument includes 34 statements divided into 6 scales. The scales are: Needs and support (needs of gifted children and support for special services), resistance to objections (objection based on ideology or priorities), social value (the social usefulness of gifted persons in 
society), rejection (the isolation of gifted persons by others in the immediate environment), ability grouping (attitudes toward special homogeneous groups, classes, schools), and school acceleration (attitudes toward accelerative enrichments). Teachers rated their attitudes using a 9-point Likertscale ranging from 1 (I totally disagree) to 9 (I totally agree).

Attitudes toward differentiated teaching for the gifted and the practical obstacles to serving gifted learners

Gagné and Nadeau's (1991) instrument is about the general attitudes toward the gifted and their education, and about the attitudes toward acceleration and ability grouping. However, one of the main methods in gifted education, especially in egalitarian contexts, is differentiated teaching. Thus, we crated16 new items to obtain more knowledge mainly about teachers' attitudes about differentiated teaching and about the practical obstacles to serving gifted learners (see Appendix 1 for a list of the added items). Teachers rated their attitudes on a 9-point Likert-scale ranging from 1 (I totally disagree) to 9 (I totally agree). Next, we will describe the information on which the added items were based.

First, we added 5 items $(36,38,40,46$ and 47$)$ intended to measure teachers' attitudes about differentiated teaching for gifted students. We particularly wanted to include items intended to determine whether teachers believed that gifted students' needs could be met through differentiated teaching in mixed-ability classrooms and whether they viewed differentiated teaching to be their responsibility as teachers. As research has shown, teachers do not necessarily include gifted students in a group viewed as needing differentiated teaching (Hertberg-Davis, 2009). Thus, it is crucial to examine whether the teachers view differentiated teaching as a method 
for addressing gifted students' needs and whether the teachers believe it is their responsibility to differentiate their teaching to address these needs.

Second, we added 3 items $(37,43$, and 49) to measure teachers' attitudes toward giftedness in special groups. Since there is ongoing discussion as well as concern about twice-exceptional students (e.g., Moon, 2009; Nicpon et al., 2011; Reis \& McCoach, 2002) and about giftedness among immigrant students (e.g., Ford, Grantham, \& Whiting, 2008; Speirs Neumeister et al., 2007), we wanted to see whether teachers in Finland feel that gifted education concerns also these groups of students. This is also an important point of view in the context of Mixed-ability teaching and differentiated teaching, where teachers should respond to students' uneven learning profiles. For example, a student might need support in one area of learning or behavior, but differentiation upward in another.

Third, we added 6 items $(41,42,44,45,48$, and 50) that measure practical obstacles to serving gifted learners in the context of differentiated teaching. According to the extant literature, many teachers seem to resist differentiated teaching because it is perceived to be extremely time consuming (Hertberg-Davis, 2009), or they report difficulties in finding and utilizing suitable resources (Davalos \& Griffin, 1999; VanTassel-Baska \& Stambaugh, 2005). There is also an ongoing debate about class sizes that are too large (Hattie, 2005). Further, identification is one of the challenges in gifted education, and since teachers play a crucial role in identifying gifted students (e.g., Bracken \& Brown, 2006), we included items to measure whether teachers feel confident about identifying giftedness in children in general, among twice-exceptional students and among immigrant students.

Finally, besides differentiated teaching, early admission to first grade, grade skipping, and subject-matter acceleration are possibilities for gifted elementary school students in Finland. 
Because Gagné and Nadeau's (1991) instrument covers only the attitudes toward grade skipping, we added items that addressed also teachers' attitudes toward subject-based acceleration (item 39) and starting school earlier (item 35).

\section{Properties of the instrument}

Since the 34 item instrument "Opinions about the gifted and their education" (Gagné \& Nadeau, 1991) had not previously been used in Finland, the first phase of the analysis included measurement of the structural validity (Byrne, 2010) by conducting confirmatory factor analysis (CFA) using Amos 22.0 software. The structural SEM was considered to have a good fit with the comparative fit index (CFI), the Tucker-Lewis index (TLI) $>.95$ and the root mean square error of approximation $($ RMSEA) $<.05$. However, an examination of model fit indices of the instrument showed that the fit was far from an acceptable: $\mathrm{Cmin} / \mathrm{df}=2.336, \mathrm{CFI}=.807, \mathrm{RMSEA}=.80$. This is similar to McCoach and Siegle's (2007) research in which they also tried to confirm the original factor structure via confirmatory factor analyses (CFA), but the model failed, resulting in an inadmissible solution.

Thus, based on the inadmissible solution of CFA, we decided to conduct exploratory factor analysis (EFA) (cf. McCoach \& Siegle, 2007). Principal axis factoring analysis was performed for all 50 items in order to examine the factor structure of the instrument with the sample of Finnish teachers. Both the Kaiser-Meyer-Olkin Measure $(\mathrm{KMO}=.722)$ and Bartlett's test of sphericity $\left(\chi^{2}\right.$ $(1225)=3696, p=.000)$ indicated that the data met criteria that are appropriate enough for factor analysis.

The initial oblique rotated (default delta) analysis yielded 14 factors with eigenvalues greater than 1 , which explained $67.72 \%$ of the total sample variation. However, inspection of the 
scree plot suggested running an eight-factor solution (Costello \& Osborne, 2005). After this analysis, 14 items were eliminated step-wise because they did not load at least .32 on any of the eight factors or they loaded equally on more than one factor (Tabachnick \& Fidell, 2001). The final analysis provided two large factors with an eigenvalue of 4.77 and 4.70 respectively, two other factors with eigenvalues greater than 2.00, and four factors having eigenvalues greater than 1.25. The final eight-factor solution consisted of 36 items and explained $57.35 \%$ of the total variance. However, a further reliability analysis of the eight factors showed that only five had an acceptable enough level of internal consistency for further statistical analyses (see Appendix 2). As an acceptable enough level of internal consistency, we used the threshold of .60, due to an exploratory approach (cf. Hair et al., 1998).

The original items yielded three factors with acceptable internal consistency. The first factor, "Special support and social value," measures attitudes toward the social value of the gifted and their need for special services. A high score on this factor indicates a positive attitude. The second factor, "Elitism," measures respondents' attitudes from the perspective of elitism. A high score indicates a negative attitude, since this implies that the respondent viewed gifted education as elitist. The third factor, "Objections to support," measures respondents' objections to gifted education based on social aspects of the gifted or gifted students' already favored situation. A high score indicates a negative attitude.

Twelve of the 16 new items loaded under three factors, of which two had acceptable internal consistency. Items of these new factors did not cross load to the earlier introduced factors. The first was called "Support for differentiation" in which a high score indicated a positive attitude toward differentiated teaching for the gifted. The second was called "Practical obstacles to serving gifted learners"; here a high score indicated that the respondent saw obstacles both to identification 
and to appropriate resources, which in turn might make gifted education difficult in practice.

\section{Results}

Teachers involved in this research were generally supportive of gifted education, indicated by the mean $5.67(S D=1.17)$ on the "Special support and social value" factor (see Appendix 2). Teachers saw that gifted students have social value and also that they need special services. However, the low mean of $3.92(S D=1.99)$ in item 2 indicates that many of the teachers in this research were against special classes for the gifted.

The mean of $4.75(S D=1.42)$ in the "Elitism" factor was near the midpoint of the scale indicating that the teachers had a neutral attitude toward the claim that gifted education is elitist. However, the teachers' responses again indicated that they did not want gifted students to be segregated, because they saw that the gifted served as intellectual stimulants for the other children (item $20 ; M=5.57, S D=1.63$ ); moreover, separating the gifted would increase labeling (item 21; $M=5.55, S D=2.01)$.

The low mean of $4.09(S D=1.23)$ in the factor "Objections to support" further indicates that teachers' attitudes were generally positive toward education of the gifted. The teachers were especially against notions that "our schools are already adequate in meeting the needs of the gifted" (item $16 ; M=3.76, S D=1.74$ ) and "the gifted are already favored in our school" (item $23 ; M=3.46$, $S D=1.84)$.

The high mean of $6.73(S D=1.42)$ in the factor "Support for differentiation" indicates that teachers were highly supportive of differentiated teaching for the gifted. The teachers unanimously viewed the responsibility for addressing gifted students' needs as being the teachers' (item 40; $M=7.34, S D=1.70)$. Finally, the high mean of $6.21(S D=1.43)$ in the factor "Practical obstacles to 
serving gifted learners" indicates that the teachers viewed gifted education in regular classrooms as challenging. The biggest obstacles were considered to be class sizes that were too large $(M=7.09, S D=2.05)$ and lack of time $(M=7.01, S D=1.93)$. The teachers also indicated that identification of the gifted, especially among immigrant children $(M=6.12, S D=1.95)$ and those with special educational needs $(M=6.38, S D=1.99)$ is difficult.

Despite the fact that the items which measured teachers' attitudes toward different types of acceleration did not form a factor (factor 6) with high enough internal consistency, it is important to report teachers' attitudes toward it, as it is the method proven to be one of the most effective academic intervention for gifted students (e.g. Assouline et al., 2015). This research showed that the teachers' attitudes toward acceleration were negative as indicated by the low means in items "A greater number of gifted children should be allowed to skip a grade" (item 34, $M=4.25$, $S D=1.85$ ), "It is more damaging for a gifted child to waste time in class than to adapt to skipping a grade" (item $8, M=4.07, S D=1.99$ ), and "Starting school one year earlier could be beneficial for many gifted pupils" (item 35, $M=4.71, S D=2.29$ ).

A correlation analysis was conducted in order to clarify the relation between the formed factors. Furthermore, we added independent variables such as age, years of teaching and school size and three background items (items 7,8 and 9; see Table 1) to the same correlation analysis to study if the chosen variables were associated with the emerged factors (see Table 2).

Pearson's correlational analyses revealed that some of the factors used in this study were related to each other. First, factor 2 was positively related with factor $3(r=.56, p<.01)$, indicating that the more the gifted education was perceived as elitist the more negative was the attitude on the scale "objections to support", i.e. more reasons to resist gifted education were seen. Furthermore, factor 2 correlated weakly with factor 4 as well: The more elitist attitude, the more 
positive attitude toward differentiated teaching. Second, factor 5 was positively related with factor 1 and factor 4 . Thus, the more positive attitude toward special support for the gifted and toward differentiated teaching for the gifted, the more the respondents saw challenges in practice.

Please insert Table 2 about here

In following, also the other statistically significant correlations are briefly explained. However, in most cases, magnitudes of these associations were weak and for this reason reader needs to be cautious when reading this section. Spearman's correlational analyses showed that age had weak negative correlation with factors 4 and 5. Similar correlational relations were found between working years and factors 4 and 5. School size did not correlate with any of the factors. Furthermore, independent sample t-test for gender revealed no differences between male and female teachers.

Spearman's correlational analyses for the three background items and their associations with the factors revealed that perceived experience in teaching the gifted (item 7) had positive correlation with factors 1 and 4 . Whereas, perceiving oneself as gifted (item 8) correlated positively with factors 1,4 and 5. Finally, having gifted in the family or vicinity (item 9) correlated positively with the factor 1 and negatively with factor 2 .

\section{Discussion}

On the whole, egalitarian cultures have been said to be hostile to gifted programs or, at best, to support gifted education in mixed-ability settings (Moon \& Rosselli, 2000). The results of this study confirmed that claim. In the egalitarian context of this research, most teachers had a positive attitude toward special support and to the social value of the gifted; moreover, they had 
highly positive attitudes toward differentiated teaching, e.g., addressing gifted students' needs in a mixed-ability setting. These results supported the conclusions of earlier research (e.g., Cross et al., 2013; Lassig, 2003) in which it has been suggested that the field of gifted education would benefit from outreach to general education and improvement of inclusive classroom practices. Further, because teachers are generally supportive of educating gifted students through differentiated teaching, efforts should be directed to the practical means of implementing such differentiation. Earlier research (Laine \& Tirri, 2016; Tirri \& Uusikylä, 1994) has indicated that, even though teachers are using differentiated teaching strategies with gifted students, they may also be employing strategies that are not effective, such as using the gifted as teachers' assistants or assigning them extra work.

Moreover, the high mean score in factor "practical obstacles in serving gifted students' needs" revealed that many teachers see challenges that hinder gifted education in practice. The greatest challenges were felt to be class sizes that are too large, and lack of time and the need for haste. This result indicates that, despite the positive nature of teachers' attitudes toward differentiated teaching for the gifted on a general level, their stance toward practice is more skeptical. Similar results have been found in research that considers teachers' attitudes about inclusion (De Boer, Pijl, \& Minnaert, 2011; Farrell, Dyson, Polat, Hutcheson, \& Gallannaugh, 2007; Moberg \& Savolainen, 2003). This might suggest that, first and foremost, teachers should be given tools for coping with and overcoming the challenges if the practice is to be improved. Teacher education should educate and inform pre-service teachers about effective differentiated teaching strategies and opportunities for addressing gifted students' needs in inclusive education (Tirri \& Laine, 2017). Further, teacher education should provide teachers more information about giftedness and skills in identifying gifted students, especially in connection with giftedness and 
identification in special groups. As this research indicates, the teachers were confident about identifying gifted students on a general level, but they felt that gifted identification was more challenging among the twice exceptional and the immigrant students.

Acceleration and groupings have been the most effective in fostering gifted students' achievement according to earlier research on the effectiveness of different kinds of interventions involving gifted students (Assouline et al., 2015; Colangelo et al., 2004a; Hattie, 2009; Wood et al., 2010). The present research indicates that Finnish teachers were mostly negative toward acceleration and they do not favor special groups for gifted students either, and in this sense, the results are in line with earlier research findings indicating that Finnish teachers prefer to keep gifted students in the same mixed-ability classes with other students (Ojanen \& Freeman, 1994; Tallent-Runnels et al., 2000; Tirri et al., 2002; Tirri \& Uusikylä, 1994).

Moreover, even though the magnitudes of the correlational associations between the factors and background items were weak, the results were in line with earlier research. For example, the correlational analysis revealed that the more experience in teaching the gifted the more positive the attitudes (cf. Bégin \& Gagné, 1994; Copenhaver \& McIntyre, 1992; Dettmer, 1985; Townsend \& Patrick, 1993). Similarly, having gifted as close contacts, in other words having gifted in the family or vicinity, was connected with more positive attitudes (cf. Bégin \& Gagné, 1994; Jung, 2014). Furthermore, results indicated that the younger teachers and teachers with less working years saw challenges in practice slightly more strongly than the other teachers, which further emphasizes the important role of teacher education, but also the support given to teachers in their transition stage. This finding is in accordance with theories of teachers' professional development that present experienced teachers as more student-centered in their thinking than the beginning teachers (Huberman, 1992). 
This study extends the research on attitudes toward the gifted and their education to cover attitudes considering differentiated teaching for the gifted, as well as to perceived challenges in gifted education. As happens in many different contexts, differentiated teaching is seen increasingly as the main pedagogical method for addressing gifted students' needs; more research is needed to examine the link between general attitudes toward the gifted and attitudes toward differentiated teaching for the gifted.

\section{Limitations}

Finally, there are some limitations that need to be addressed. The main limitations are connected to the sample used for this research. First, the number of respondents was low, which might affect the generalizability of the results. Although the sample was representative of the distributions of age and gender of teachers in Finland (see Participants section), there still might be a voluntary response bias. It might be that, because answering our questionnaire was voluntary, those teachers who had a positive attitude toward gifted education or valued it as being important were more likely to answer than teachers with more negative or indifferent attitudes. Hereby, caution should be exercised in interpreting these results.

The main caveat of this study comes from the fact that we planned to validate the factor structure of a Finnish version of the "Opinions about the gifted and their education" measure (Gagné \& Nadeau, 1991). Similar to McCoach and Siegle's (2007) study, we were not able to verify the structural validity of this measure. Thus, caution is needed in generalizing the results. International validation of Gagné and Nadeau's measure calls for more research, as well as the "Differentiated teaching for the gifted" measure developed in this study requires more evidence of its applicability. In the future, new data should be gathered, and the model fit of the factor structure 
found in EFA to be confirmed and determined using CFA. That would shed light on whether the found factor structure was specific only for this study's data or whether it is something that works with different data as well. 


\section{References}

Ajzen, I. (2001). Nature and operation of attitudes. Annual Review of Psychology, 52, 27-58.

Ajzen, I., \& Fishbein, M. (2000). Attitudes and the attitude-behavior relation: reasoned and automatic processes. European Journal of Social Psychology, 11(1), 1-33.

Archambault, F., Westberg, K., Brown, S., Hallmark, B., Emmons, C., \& Zhang, W. (1993). Regular classroom practices with gifted students: Results of a national survey of classroom teachers (Research monograph 93102). Storrs: University of Connecticut, National Research Center on the Gifted and Talented.

Assouline, S.G., Colangelo, N., VanTassel-Baska, J., \& Lupkowski-Shoplik, A. (2015). Introduction. In S. G. Assouline, N. Colangelo, J. VanTassel-Baska, \& A. LupkowskiShoplik (Eds.). A nation empowered: evidence trumps the excuses holding back America's brightest students, volume 2 (pp. 1-6). Cedar Rapids, IA: Colorweb printing.

Atjonen, P., et al. (2008). Tavoitteista vuorovaikutukseen [From goals to interaction] (Report of the Finnish Education Evaluation Council No. 30). Retrieved from http://karvi.fi/app/uploads/2014/09/KAN_30.pdf

Bégin, J., \& Gagné, F. (1994). Predictors of a general attitude toward gifted education. Journal for the Education of the Gifted, 18(1), 74-86.

Bracken, B.A., \& Brown, E.F. (2006). Behavioral identification and assessment of gifted and talented students. Journal of Psychoeducational Assessment, 24(2), 112-122.

Brighton, C. M., Hertberg, H. L., Moon, T. R., Tomlinson, C. A., \& Callahan, C. M. (2005). The Feasibility of High-end Learning in a Diverse Middle School. (Research Monograph RM05210). Charlottesville, VA: National Research Center on the Gifted and Talented. 
Byrne, B.M. (2010). Structural equation modeling with AMOS: basic concepts, applications, and programming. New York, NY: Routledge.

Colangelo, N., Assouline, S., \& Gross, M. (2004a). A Nation Deceived: How Schools Hold Back America's Brightest Students, volume 1. Retrieved April 9, 2015, from https://www.templeton.org/sites/default/files/Nation_Deceived_Both_Volumes.pdf

Colangelo, N., Assouline, S., \& Gross, M. (2004b). A Nation Deceived: How Schools Hold Back America's Brightest Students, volume 2. Retrieved April 9, 2015, from https://www.templeton.org/sites/default/files/Nation_Deceived_Both_Volumes.pdf

Copenhaver, R., \& McIntyre, D. (1992). Teachers' perception of gifted students. Roeper Review, $14,151-153$.

Costello, A.B., \& Osborne, J. W. (2005). Best practices in exploratory factor analysis: four recommendations for getting the most from your analysis. Practical Assessment, Research \& Evaluation, 10(7), 1-9.

Crano, W.D., \& Prislin, R. (2006). Attitudes and persuasion. Annual Review of Psychology, 57, $345-374$.

Cross, J.R., Cross, T., \& Frazier, A.D. (2013). Student and teacher attitudes toward giftedness in a two laboratory school environment: a case for conducting a needs assessment. NALS Journal, 5(1), 1-21.

Davalos, R., \& Griffin, G. (1999). The impact of teachers' individualized practices on gifted students in rural, heterogeneous classrooms. Roeper Review, 21(4), 308-314.

De Boer, A., Pijl, S. J., \& Minnaert, A. (2011). Regular primary schoolteachers' attitudes towards inclusive education: a review of the literature. International Journal of Inclusive Education, 15(3), 331-353. 
Dettmer, P. (1985). Attitudes of school role groups toward learning needs of gifted students. Roeper Review, 7(4), 72-76.

Farrell, P., Dyson, A., Polat, F., Hutcheson, G., \& Gallannaugh, F. (2007). Inclusion and achievement in mainstream schools. European Journal of Special Needs Education, 22(2), 131-145.

Finn, C.E., \& Wright, B.L. (2015). Failing our brightest kids: the global challenge of educating high-ability students. Cambridge, MA: Harvard education press.

FNBE (2004). Perusopetuksen opetussuunnitelman perusteet 2004. [National Core Curriculum in Basic Education 2004]. Vammala, Finland: Vammalan kirjapaino.

FNBE (2011). Perusopetuksen opetussuunnitelman perusteiden muutokset ja täydennykset 2010. [Amendments and Additions to the National Core Curriculum for Basic Education]. Tampere, Finland: Tampereen Yliopistopaino.

FNBE (2014). Perusopetuksen opetussuunnitelman perusteet 2014. [National Core Curriculum in Basic Education 2014]. Tampere, Finland: Suomen yliopistopaino.

Ford, D.Y., Grantham, T.C., \& Whiting, G.W. (2008). Culturally and linguistically diverse students in gifted education: recruitment and retention issues. Exceptional Children, 74, 289-306.

Gagné, F., \& Nadeau, L. (1991). Opinions about the gifted and their education. Unpublished instrument.

Gagné, F., \& Nadeau, L. (1985). Dimensions of attitudes toward giftedness. In A. H. Roldan (Ed.). Gifted and talented children, youth and adults: their social perspective and culture (pp. 148-170). Monroe, NJ: Trillium Press. 
Hair, J.F., Anderson, R.E., Tatham, R.I., \& Black, W.C. (1998). Multivariate Data Analysis (5 ${ }^{\text {th }}$ ed). New York, NY: Macmillan.

Hattie, J. (2005). The paradox of reducing class size and improving learning outcomes. International Journal of Educational Research, 43(6), 387-425.

Hattie, J. (2009). Visible Learning: a Synthesis of Over 800 meta-analyses relating to achievement. London and New York: Routledge.

Hertberg-Davis, H. (2009). Myth 7: differentiation in the regular classroom is equivalent to gifted programs and is sufficient. Classroom teachers have the time, the skill, and the will to differentiate adequately. Gifted Child Quarterly, 53(4), 251-253.

Huberman, A.M. (1992). The lives of teachers. London: Cassell.

Jones, E., \& Southern, W. (1992). Programming, grouping, and acceleration in rural school districts: A survey of attitudes and practices. Gifted Child Quarterly, 36(2), 112-117.

Jung, J.Y. (2014). Predictors of attitudes to gifted programs/provisions: evidence from preservice educators. Gifted Child Quarterly, 58(4), 247-258.

Kumpulainen, T. (2011). Opettajat Suomessa 2010 [Teachers in Finland 2010]. Tampere: Tammerprint Oy. Retrieved from http://www.oph.fi/download/131532_Opettajat_Suomessa_2010.pdf

Kumpulainen, K., \& Lankinen, T. (2012). Striving for educational equity and excellence: evaluation and assessment in Finnish basic education. In: H. Niemi, A. Toom, \& A. Kallioniemi (Eds.), The Miracle of Education: The Principles and Practices of Teaching and Learning in Finnish Schools (pp. 69-81). Rotterdam/Boston/Taipei: Sense Publisher. Kuparinen, S. (1995). Lahjakkaiden oppilaiden asema Helsingin peruskoulujen ala-asteilla opettajien kokemana. Tutkimus kvalitatiivisen tasa-arvon toteutumisesta. [Classteachers' 
experiences of situation of the gifted pupils in Helsinki primary schools. Study about qualitative equality]. Helsingin kaupunki: Helsingin kaupungin opetusviraston julkaisusarja, B23:1995.

Laine, S. (2010). The Finnish public discussion of giftedness and gifted children. High Ability Studies, 21(1), 63-76.

Laine, S., \& Tirri, K. (2016). How Finnish elementary school teachers meet the needs of their gifted students. High Ability Studies, 27(2), 149-164.

Lassig, C. J. (2003) Gifted and talented education reforms: Effects on teachers' attitudes. In B. Bartlett, F. Bryer, \& D. Roebuck (Eds.), Proceedings 1st Annual International Conference on Cognition, Language, and Special Education Research: Reimagining Practice: Researching Change 2, 141-152.

Lassig, C.J. (2009). Teachers' attitudes towards the gifted: the importance of professional development and school culture. Australian Journal of Gifted Education, 18(2), 32-42.

Latz, A. O., Speirs Neumeister, K. L., Adams, C. M., \& Pierce, R.L. (2009). Peer coaching to improve classroom differentiation: perspectives from project CLUE. Roeper Review, $31(1), 27-39$.

McCoach, B.D., \& Siegle, D. (2007). What predicts teachers' attitudes toward the gifted? Gifted Child Quarterly, 51(3), 246-255.

Megay-Nespoli, K. (2001). Beliefs and attitudes of novice teachers regarding instruction of academically talented learners. Roeper Review, 23(3), 178-182.

Moberg, S., \& Savolainen, H. (2003). Struggling for inclusive education in the North and the South: Educators' perceptions on inclusive education in Finland and Zambia. International Journal of Rehabilitation Research, 26(1), 21-31. 
Moon, S.M. (2009). Myth 15: High ability students don't face problems and challenges. Gifted Child Quarterly, 53(4), 274-276.

Moon, S. M., \& Rosselli, H.C. (2000). Developing gifted programs. In K.A. Heller, F.J. Mönks, \& R.F. Subotnik (Eds.), International Handbook of Giftedness and Talent (pp. 499-521). Amsterdam, Netherlands: Elsevier Science.

Moon, T.R., Callahan, C.M., \& Tomlinson, C.A. (1999). The effects of mentoring relationships on preservice teachers' attitudes toward academically diverse students. Gifted Child Quarterly, 43(2), 56-62.

Morris, S. (1987). Student teachers' attitudes toward gifted students. The Creative Child and Adult Quarterly, 12(2), 112-114.

Mönks, F.J., \& Katzko, M.W. (2005). Giftedness and gifted education. In R. J. Sternberg \& J. E. Davidson (Eds.), Conceptions of Giftedness (pp. 187-201). New York, NY: Cambridge University Press.

Mönks, F. J., \& Pflüger, R. (2005). Gifted Education in 21 European Countries: Inventory and Perspective. Radboud, Netherlands: University Nijmegen.

Nicpon, M.F., Allmon, A., Sieck, B., \& Stinson, R.D. (2011). Empirical investigation of twice exceptionality: where have we been and where are we going? Gifted Child Quarterly, 55(1), 3-17.

Niemi, H. (2012). The social factors contributing to education and schooling in Finland. In H. Niemi, A. Toom, \& A. Kallioniemi (Eds.), Miracle of Education (pp. 19-38). Rotterdam/Boston/Taipei: Sense Publisher. 
Ojanen, S. \& Freeman, J. (1994). The attitudes and experiences of headteachers, class-teachers, and highly-able pupils towards the education of the highly able in Finland and Britain. Research Reports of the faculty of Education No 54. University of Joensuu.

Persson, R. (2011). Ability climates in Europe as socially represented notability. High Ability Studies, 22(1), 79-101.

Reis, S.M., \& McCoach, D.B. (2002). Underachievement in gifted and talented students with special needs. Exceptionality, 10(2), 113-125.

Richardson, V. (1996). The role of attitudes and beliefs in learning to teach. In J. Sikula (Ed.), Handbook of Research on Teacher Education (pp. 102-119). New York, NY: MacMillan.

Simola, H., Rinne, R., Kivirauma, J. (2002). Abdication of the education state or just shifting responsibilities? The appearance of a new system of reason in constructing educational governance and social exclusion/inclusion in Finland. Scandinavian Journal of Educational Research, 46(3), 247-264.

Speirs Neumeister, K. L., Adams, C. M., Pierce, R. L., Cassady, J.C., \& Dixon, F.A. (2007). Fourth-grade teachers' perceptions of giftedness: implications for identifying and serving diverse gifted students. Journal for the Education of the Gifted, 30(4), 478-499.

Tabachnick, B. G., \& Fidell, L. S. (2001). Using Multivariate Statistics. Boston, MA: Allyn and Bacon.

Tallent-Runnels, M.K., Tirri, K.A., \& Adams, A.M. (2000). A cross-cultural study of teachers' attitudes toward gifted children and programs for gifted children. Gifted and Talented International, 15(2), 103-115.

Tirri, K. (2014). The last 40 years in Finnish teacher education. Journal of Education for 
Teaching, 40(5), 1-10.

Tirri, K., \& Kuusisto, E. (2013). How Finland serves gifted and talented pupils. Journal for the Education of the Gifted, 36(1), 84-96.

Tirri, K., \& Laine, S. (2017). Teacher education in inclusive education. In D.J. Clandinin \& J. Husu (Eds.), The Sage Handbook of Research on Teacher Education (pp. 761-776). Los Angeles, CA: Sage.

Tirri, K., Tallent-Runnells, M., Adams, A., Yuen, M., \& Lau, P. (2002). Cross-cultural predictors of teachers' attitudes toward gifted education: Finland, Hong Kong, and the United States. Journal for the Education of the Gifted, 26(2), 112-131.

Tirri, K. \& Uusikylä, K. (1994). How teachers perceive differentiation of education among the gifted and talented. Gifted and Talented International, 9(2), 69-73.

Tomlinson, C. A. (1999). The Differentiated Classroom: Responding to the Needs of All Learners. Upper Saddle River, NJ: Pearson Education.

Townsend, M., \& Patrick, H. (1993). Academic and psychosocial apprehensions of teachers and teacher trainees toward the educational acceleration of gifted children. New Zealand Journal of Educational Studies, 28(1), 29-41.

Troxclair, D. A. (2013). Preservice teacher attitudes toward giftedness. Roeper Review, 35(1), $58-64$.

VanTassel-Baska, J., \& Stambaugh, T. (2005). Challenges and possibilities for serving gifted learners in the regular classroom. Theory into Practice, 44(3), 211-217.

Westberg, K. L., Archambault, F. X, \& Brown, S. W. (1997). A survey of classroom practices with third and fourth grade students in the United States. Gifted Education International, 12(1), 29-33. 
Westberg, K.L., Archambault, F. X., Dobyns, S. M., Salvin, T.J. (1993). An observational study of instructional and curricular practices used with gifted and talented students in regular classrooms. (Research monograph 93104). Storrs: University of Connecticut, National Research Center on the Gifted and Talented.

Wood, S., Portman, T., Cigrand, D. L., \& Colangelo, N. (2010). School counselors’ perceptions and experience with acceleration as a program option for gifted and talented students. Gifted Child Quarterly, 54(3), 168-178. 
Dr. Sonja Laine is a lecturer at the Viikki Teacher Training School of the University of Helsinki and a postdoctoral researcher at the Department of Education at the University of Helsinki. Laine has served as a national delegate of the WCGTC (World Council of Gifted and Talented Children) since 2015.

Dr. Risto Hotulainen is an Associate Professor of Educational Assessment and Director of Centre for Educational Assessment belonging to the Faculty of Education Sciences at the University of Helsinki. Hotulainen has been the national correspondent of ECHA (European Council for High Ability) since 2006 .

Dr. Kirsi Tirri is a Professor of Education and Research Director at the Helsinki Collegium for Advanced Studies and Department of Education at the University of Helsinki, Finland. She is also a visiting Professor at St. John's University, New York, USA and University of Tallinn, Estonia. Tirri has been the President of ECHA (European Council for High Ability) for the years 20082012, the President of the SIG International Studies at AERA (American Educational Research Association) for the years 2010-2013 and the President of the Finnish Academy of Science and Letters for the years 2016-2017. 